\title{
Comparative Study of Chemical and Mechanical Retentive Systems for Bonding of Indirect Composite Resin to Commercially Pure Titanium
}

\author{
Adriana Cláudia Lapria FARIA \\ Rodrigo Lino de MATOS \\ Renata Cristina Silveira RODRIGUES \\ Rossana Pereira de Almeida ANTUNES \\ Ricardo Faria RIBEIRO \\ Maria da Gloria Chiarello de MATTOS \\ Department of Dental Materials and Prosthodontics, Dental School of Ribeirão Preto, \\ University of São Paulo, Ribeirão Preto, SP, Brazil
}

\begin{abstract}
This study evaluated the effect of chemical and mechanical surface treatments for cast metal alloys on the bond strength of an indirect composite resin (Artglass) to commercially pure titanium (cpTi). Thirty cylindrical metal rods (3 mm diameter x $60 \mathrm{~mm}$ long) were cast in grade- $1 \mathrm{cpTi}$ and randomly assigned to 6 groups $(\mathrm{n}=5)$ according to the received surface treatment: sandblasting; chemical treatment; mechanical treatment $-0.4 \mathrm{~mm}$ beads; mechanical treatment $-0.6 \mathrm{~mm}$ beads; chemical/mechanical treatment $-0.4 \mathrm{~mm}$; and chemical/ mechanical treatment $-0.6 \mathrm{~mm}$ beads. Artglass rings ( $6.0 \mathrm{~mm}$ diameter x $2.0 \mathrm{~mm}$ thick) were light cured around the cpTi rods, according manufacturer's specifications. The specimens were invested in hard gypsum and their bond strength (in MPa) to the rods was measured at fracture with a universal testing machine at a crosshead speed of $2.0 \mathrm{~mm} / \mathrm{min}$ and $500 \mathrm{kgf}$ load cell. Data were analyzed statistically by one-way ANOVA and Tukey test $(\alpha=5 \%)$. The surface treatments differed significantly from each other $(\mathrm{p}<0.05)$ regarding the recorded bond strengths. Chemical retention and sandblasting showed statistically similar results to each other $(\mathrm{p}=0.139)$ and both had significantly lower bond strengths $(\mathrm{p}<0.05)$ than the other treatments. In conclusion, mechanical retention, either associated or not to chemical treatment, provided higher bond strength of the indirect composite resin to cpTi.
\end{abstract}

Key Words: composite resin, titanium, bond strength.

\section{INTRODUCTION}

Metals are susceptible to biodegradation in the oral environment due to a combination of dissolution in saliva, wear and corrosion, mainly when different metals and alloys are used. Titanium is known to have an excellent corrosion resistance due to the formation of a thermodynamically and mechanically stable oxide layer on its surface (1). However, the presence of an excess oxide layer is a possible cause of decreased bonding durability (2).

The deficient bonding of indirect composites to the metallic alloys could promote the formation of marginal gaps, causing weak bond strength and color change, which affect directly esthetics. Several adhesive systems have been introduced in an attempt to solve this problem (3). Retention of indirect composites for fixed prosthesis and crowns to metallic frameworks can be obtained by micromechanical (air-abrasion, electrolytic etching, porous metal coating), macromechanical (mesh, beads, rough surface with particles) and chemical (4-META composites, phosphate-based composites) procedures, and adhesive layer application (tin plating, silanization) (3-5).

Siloc MD chemical system (Heraeus Kulzer $\mathrm{GmbH}$, Wehrheim, Germany) is based on the principle

Correspondence: Profa. Dra. Maria da Gloria C. de Mattos, Departamento de Materiais Dentários e Prótese, Faculdade de Odontologia de Ribeirão Preto, USP, Avenida do Café, S/N, 14040-904 Ribeirão Preto, SP, Brasil. Tel: +55-16-3602-4005. Fax: +55-16-3633-0999. email: gloria@forp.usp.br 
of burning silica on a metallic alloy and has shown bond strengths comparable to those obtained by traditional methods. As far as dental prostheses are concerned, more favorable results are obtained in adhesive prostheses, metal-composite fixed partial denture and crowns, telescopic crowns, and removable partial dentures. An additional advantage of this system is the possibility of being used with noble or alternative alloys $(6,7)$.

Silanization has been advocated by several authors. As marginal gap formation between composite and metal may lead to bacterial biofilm formation and compromise esthetics, the use of a hydrophobic polymer (Silicoater; Heraeus Kulzer GmbH) has been proposed to provide a composite-to-metal bond with higher resistance to hydrolysis (8). However, the association of chemical and mechanical (retentive beads) retention systems recommended for bonding composites to cast metal alloys could a provide good retention and avoiding microgap formation $(3,6,7,9)$. The bond strength of an indirect composite veneering material to cast magnetic Fe-Pt alloy has been previously studied (10).

This study evaluated the effect of chemical and mechanical surface treatments for cast metal alloys on the bond strength of an indirect composite resin (Artglass) to commercially pure titanium (cpTi).

\section{MATERIAL AND METHODS}

Thirty specimens were made using cylindrical brass rods ( $3 \mathrm{~mm}$ diameter x $60 \mathrm{~mm}$ long) invested in a special investment (Rematitan Plus; Dentaurum, Pforzheim, Germany). When mechanical retention was used, an adhesive layer (colorless nail polish; Colorama, São Paulo, SP, Brazil) was applied in one of the ends of the cylindrical brass rods (area of $18 \mathrm{~mm}^{2}$ ), and then 0.4 $\mathrm{mm}$ or $0.6 \mathrm{~mm}$ diameter beads (Renfert, Hilzingen, Germany) were sprayed onto the adhesive layer. After investment setting and removal of the cylindrical brass rods, the casting rings were preheated in a furnace (EDG 7000 3P; EDG Equipamentos e Controles Ltda., São Carlos, SP, Brazil), according to manufacturer's instructions. Grade-1 cpTi (Tritan; Dentaurum) was melted in a double-chamber machine (Rematitan; Dentaurum) by voltaic arc, under vacuum and argon atmosphere, with metal injection into the mold by vacuum-pressure.

After casting, the cpTi rods (Fig. 1) were divested and cleaned with carbide burs (\#702L; KG
Sorensen Ind. e Com. Ltda., Barueri, SP, Brazil), airborne particle blasted with aluminum oxide particles approximately $250 \mu \mathrm{m}$ in size for $120 \mathrm{~s}$, under a pressure of 3 bar (42 psi). All cpTi specimens were sandblasted. Five specimens were cast for each of the six retention treatments accomplished on metal surface before application of the veneering composite (Artglass; Heraeus Kulzer $\mathrm{GmbH}$ ): sandblasting; chemical treatment; mechanical treatment - $0.4 \mathrm{~mm}$ beads; mechanical treatment $-0.6 \mathrm{~mm}$ beads; chemical/mechanical treatment - $0.4 \mathrm{~mm}$; and chemical/mechanical treatment - $0.6 \mathrm{~mm}$ beads. As cast specimens are routinely submitted to sandblasting, this treatment served as a control.

For the silanization technique and fabrication of the composite rings, the specimens allocated to receive chemical treatment were fixed to the Siloc Tray (Heraeus Kulzer $\mathrm{GmbH}$ ), brushed with a layer of Siloc Pre, which was allowed to dry for $2 \mathrm{~min}$, placed in the ceramic holder inside the silanization unit, and heated at approximately $300^{\circ} \mathrm{C}$ for $6 \mathrm{~min}$.

After natural cooling of the specimens, the area that would receive the composite was separated by 2 silicone cylinders (Optosil; Bayer, Leverkusen, Germany) using a polyester spacer (Plexiglass; General Electric, Vernon, Ind., USA) (Fig. 2). Then, Siloc Bond (Heraeus Kulzer GmbH), an impermeable supercrosslinked urethane composite, was uniformly applied. After waiting $5 \mathrm{~min}$ for activation and drying to occur, a thin layer $(\sim 0.1 \mu \mathrm{m})$ of Artglass opaque paste (Heraeus Kulzer $\mathrm{GmbH}$ ) was applied with a brush and fully polymerized for $90 \mathrm{~s}$ in the

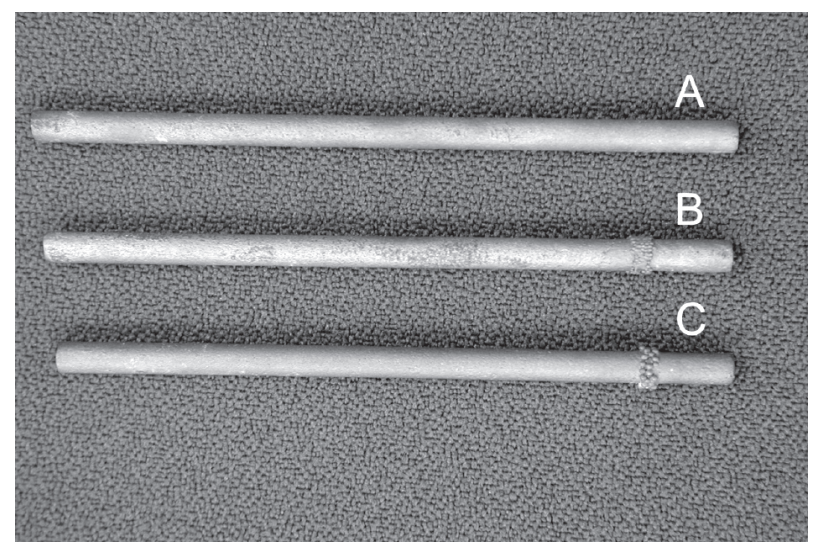

Figure 1. A= Cylindrical metallic rods cast in cpTi without mechanical retention; $\mathrm{B}=$ mechanical retention with $0.4 \mathrm{~mm}$ beads; $\mathrm{C}=$ mechanical retention with $0.6 \mathrm{~mm}$ beads. 
light-curing unit (UniXS; Heraeus Kulzer GmbH), which has two xenon strobe lamps (wavelength range: 320$520 \mathrm{~nm} ; 270 \mathrm{~W} ; 20 \mathrm{~Hz}$ ). After activation, the composite was stratified into two phases with the aid of a spatula, and then brushed with a fine layer of modeling liquid Artglass to help shape the composite externally. The specimens were placed in the light-curing unit (UniXS) again for $180 \mathrm{~s}$ in each phase.

In order to perform the metal-composite tensile bond strength test with the control group and mechanical retention groups $(0.4 \mathrm{~mm}$ or $0.6 \mathrm{~mm}$ beaded rod), Artglass composite rings were fabricated without application of chemical retention. The metal-composite bond strength test require individual measurement of specimens (9). Two measurements, perpendicular to

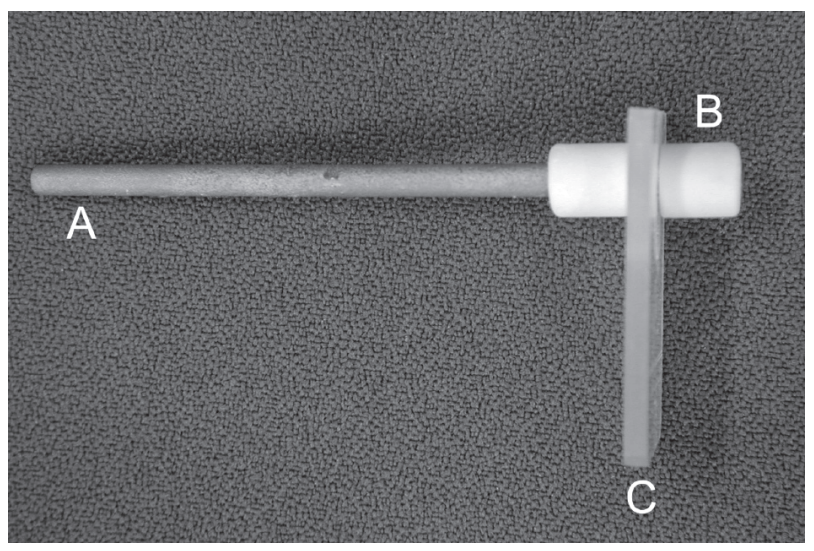

Figure 2. Cylindrical metallic rod (A) with silicone slide (B) and polyester spacer (C).

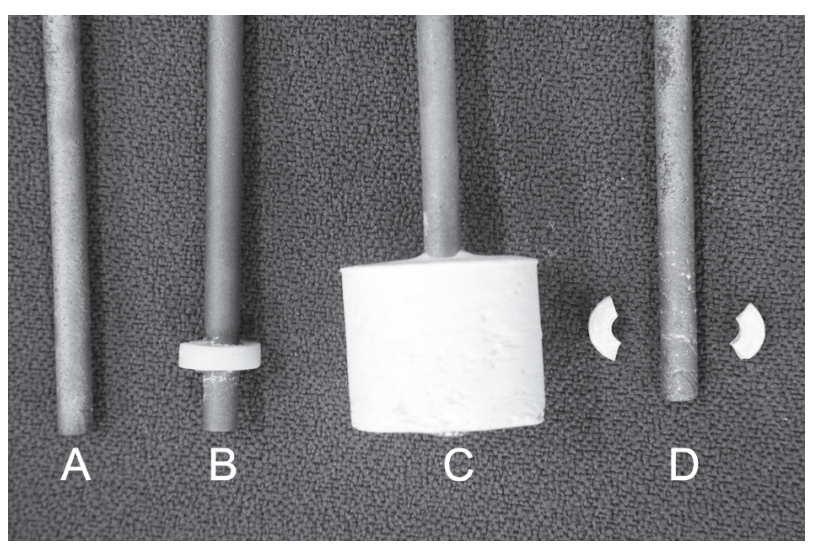

Figure 3. $\mathrm{A}=\mathrm{cpTi}$ rod; $\mathrm{B}=\mathrm{cpTi}$ rod with composite ring; $\mathrm{C}=$ specimen invested in gypsum; $\mathrm{D}=$ fractured resin ring. each other, were taken from the cylindrical rod diameter immediately above and below the ring, as well as 4 equally-distanced measurements of the composite ring thickness. The mean value of these 4 measurements was assumed to represent the cylindrical rod diameter and the composite ring thickness, respectively. Such mean values were used to calculate the metal-composite bond area with the equation : $S=\pi . \phi . \varepsilon$, where $S=$ metalcomposite bond area, $\phi=$ rod diameter and $\varepsilon=$ composite ring thickness.

The composite rings were embedded in the center of a PVC cylinder using hard gypsum (Vigodent S.A. Ind. e Com., Rio de Janeiro, RJ, Brazil) and a dental surveyor (Bio-Art Equipamentos Odontológicos Ltda., São Carlos, SP, Brazil). After the gypsum had set, the $\mathrm{PVC}$ rings were removed from the specimens and pulled in a universal testing machine (EMIC MEM 2000; EMIC Equipamentos e Sistemas de Ensaio Ltda., São José dos Pinhais, PR, Brazil) until fracture. The test was carried out in a standardized manner at a constant crosshead speed of $2.0 \mathrm{~mm} / \mathrm{min}$ and $500 \mathrm{kgf}$ load cell (Fig. 3) (9). The rupture peak load was used to calculate the bond strength, by the equation: $B S=F / S$, where: $\mathrm{BS}$ = bond strength, $F=$ critical rupture load, $S=$ metalcomposite bond area.

All groups were submitted to one-way ANOVA and complementary Tukey test $(\alpha=5 \%)$ using the SPSS 12.0 for Windows statistical software (SPSS Inc., Chicago, IL, USA).

\section{RESULTS}

The metal-composite bond tensile strength mean values are presented in Table 1. Statistical analysis

Table 1. Bond strength means $( \pm \mathrm{SD})$ for the surface treatments.

\begin{tabular}{lc}
\hline Retention systems & Mean (SD) \\
\hline Sandblasting & $29.19 \pm 5.87 \mathrm{a}$ \\
Chemical treatment & $35.13 \pm 4.46 \mathrm{a}$ \\
$0.4 \mathrm{~mm}$ mechanical beads & $44.41 \pm 2.11 \mathrm{~b}$ \\
$0.6 \mathrm{~mm}$ mechanical beads & $45.16 \pm 6.31 \mathrm{~b}$ \\
$0.4 \mathrm{~mm}$ chemical and mechanical beads & $47.03 \pm 5.77 \mathrm{~b}$ \\
$0.6 \mathrm{~mm}$ chemical and mechanical beads & $49.15 \pm 9.67 \mathrm{~b}$ \\
\hline
\end{tabular}

Different letters indicate statistically significant difference at 5\% (one-way ANOVA and Tukey test). 
showed statistically significant difference $(\mathrm{p}<0.05)$ between the retention systems, comparing for bond strength means. Chemical retention and sandblasting showed statistically similar results to each other $(\mathrm{p}=0.139)$ and both presented significantly lower bond strengths than the other surface treatments $(\mathrm{p}<0.05)$.

\section{DISCUSSION}

Light-cured veneering materials have become an alternative to porcelain because of favorable esthetics, abrasion similar to natural tooth, reparability, and fast, simple laboratory techniques (11). Furthermore, some authors have suggested the use of composites as veneering materials of implant-supported dentures to reduce stress endured under different loading conditions by $15 \%$, when compared to equivalent thicknesses of porcelain or metal (12).

It is known that the bonding between cpTi and veneering materials can be affected by the oxide layer. While some authors have reported that composites adhere to cpTi effectively due to the passive oxide film that forms on its surface (4), others believe that the presence of an excess surface oxide layer is a possible cause of decreased bonding durability (2). Present study simulated a laboratorial sequence for clinical use; the oxide film was not evaluated.

Fracture or detachment of denture parts frequently occurs at the interface between different materials, such as the resin-metal interface. So, the bond strength between composites and titanium alloys is therefore an important factor in the durability of fixed prostheses (13). As a result, beads, wires or loops in metal design have been purposed to enhance the attachment of the resin composite to the cast frameworks (7). In the present study, using $0.4 \mathrm{~mm}$ and $0.6 \mathrm{~mm}$ beads, the bond strength has improved independently of a chemical treatment. Nevertheless, mechanical retention results in a bulkier framework that is difficult to opaque because of the pooling around the beads (11). As the results of the present study showed that the bond strength was not affected by the diameter of the beads, the use of small beads should be preferred.

One disadvantage of the mechanical retention is that the gap between the veneering material and the metal can allow the filling of the gap with oral fluids causing odors and discoloration, and hence affecting the esthetics of the veneer. Therefore, some authors have argued that chemical bonding provide more desirable results than mechanical bonding (11). According to Petridis et al. (14), the addition of chemical bonding reduces bond degradation in a corrosive environment.

Studies evaluating metal-composite chemical bonding systems (4-META and Silicoater MD) have found higher bond strength for chemical systems, when compared to mechanical ones, minimizing the formation of cracks at the metal-composite interface $(5,15,16)$. In the present study, the bond strengths of composite to cpTi treated chemically were similar to those recorded in the control group (sandblasting). However, a comparison between chemical and mechanical treatments showed that mechanical retention was greater than chemical. These results are consistent with those of a previous study (3).

The association of chemical and mechanical surface treatments has been proposed to combine greater retention and fill the gaps between metal and veneering material. Vojvodic et al. (6) have found higher bond strengths when chemical retention was used in combination with mechanical retention, in the same way as reported in a previous study (9) that compared chemical, mechanical and chemical-mechanical treatments. Likewise, in the present study, the best retention result was obtained when mechanical and chemical treatments were associated. Although the bond strengths recorded in the chemical/mechanical treatment groups were statistically similar to those recorded with mechanical treatment alone, the association of treatments has advantages such as prevention of marginal gaps through which oral fluids could penetrate, causing discoloration and compromising the esthetics of the composite veneer.

It should be considered that, in this study, the specimens were not subjected to any thermocycling regimen, and studies testing adhesive strength to metals have noted lower bond strength after thermocycling, demonstrating an adverse effect of fluids and temperature variation at the metal-composite interface $(4,13,17,18)$. A study that evaluated two silane solutions prior to bonding composite to titanium, some specimens had the composite de-bonded from the silanized titanium substrate after 3,700 thermal cycles (19).

Within the limitations of the present study, it may be concluded that mechanical retention either associated or not to chemical treatment provided higher bond strength of the indirect composite resin to cpTi. 


\section{RESUMO}

Este estudo avaliou o efeito de tratamentos de superfície químico e mecânico para ligas metálicas fundidas sobre a resistência de união de uma resina composta indireta (Artglass) ao titânio comercialmente puro (Ti cp). Trinta varetas cilíndricas metálicas (3 mm diâmetro $\mathrm{x} 60 \mathrm{~mm}$ comprimento) foram fundidas em Ti cp grau 1 e igualmente divididas em grupos de acordo com os seguintes tratamentos de superfície: jateamento, químico, mecânico com esferas de $0,4 \mathrm{~mm}$, mecânico com esferas de $0,6 \mathrm{~mm}$, químico/ mecânico com esferas de 0,4 mm e químico/mecânico com esferas de $0,6 \mathrm{~mm}$. Anéis de Artglass ( $6 \mathrm{~mm}$ diâmetro X $2 \mathrm{~mm}$ espessura) foram fotopolimerizados ao redor das varetas, de acordo com as recomendações do fabricante. Os corpos-de-prova foram embutidos em gesso-pedra e a resistência de união (MPa) foi medida em uma máquina universal de ensaios com velocidade de $2,0 \mathrm{~mm} / \mathrm{min}$ e célula de carga de $500 \mathrm{kgf}$. Os dados foram analisados estatisticamente por ANOVA a um critério e teste de Tukey $(\alpha=5 \%)$. Houve diferença estatisticamente significante $(\mathrm{p}<0,05)$ entre os tratamentos de superfície quanto à resistência adesiva. Retenção química e jateamento apresentaram resultados estatisticamente semelhantes $(\mathrm{p}=0,139)$, e ambos apresentaram menores valores de retenção que os demais tratamentos $(\mathrm{p}<0,05)$. Em conclusão, a retenção mecânica, associada ou não a tratamento químico, apresentou melhores resultados de resistência adesiva do compósito indireto ao Ti cp.

\section{ACKNOWLEDGEMENTS}

This study was supported by the São Paulo Research Foundation (FAPESP; Grant \#98/13072-8). Thanks to Prof. Dr. Osvaldo Luiz Bezzon for the use of the Rematitan machine.

\section{REFERENCES}

1. Lygre H. Prosthodontic biomaterials and adverse reactions: a critical review of the clinical and research literature. Acta Odontol Scand 2002;60:1-9.

2. Taira Y, Matsumura H, Yoshida K, Tanaka T, Atsuta M. Influence of surface oxidation of titanium on adhesion. $\mathrm{J}$ Dent 1998;26:69-73.

3. Jones RM, Moore BK, Goodacre CJ, Munoz-Viveros CA. Microleakage and shear bond strength of resin and porcelain veneers bonded to cast alloys. J Prosthet Dent 1991;65:221228.

4. Fujishima A, Fujishima Y, Ferracane JL. Shear bond strength of four commercial bonding systems to CpTi. Dent Mater 1995;11:82-86

5. Ishijima T, Caputo AA, Mito R. Adhesion of resin to casting alloys. J Prosthet Dent 1992;67:445-449.
6. Vojvodic D, Predanic-Gasparac H, Brkic H, Celebic A. The bond strength of polymers and metal surfaces using the "Silicoater" technique. J Oral Rehabil 1995;22:493-499.

7. Watanabe I, Kurtz KS, Kabcenell JL, Okabe T. Effect of sandblasting and silicoating on bond strength of polymerglass composite to cast titanium. J Prosthet Dent 1999;82:462-467.

8. Chang JC, Koh SH, Powers JM, Duong JH. Tensile bond strengths of composites to a gold-palladium alloy after thermal cycling. J Prosthet Dent 2002;87:271-276.

9. Tarozzo LSA, Mattos MGC, Ribeiro RF, Semprini, M. Comparison of retentive systems for composites used as alternatives to porcelain in fixed partial dentures. J Prosthet Dent 2003;89:572-578.

10. Ohkubo C, Kono H, Tanaka Y, Watanabe I. Shear bond strength of resin composite to magnetic Fe-Pt alloy. J Prosthet Dent 2005;93:478-482.

11. Ciftci Y, Canay S, Hersek N. Shear bond strength evaluation of different veneering systems on Ni-Cr alloys. J Prosthodont 2007; 16:31-36.

12. Ciftci Y, Canay S. The effect of veneering materials on stress distribution in implant-supported fixed prosthetic restorations. Int J Oral Maxillofac Implants 2000;15:571-582.

13. Yanagida H, Taira Y, Shimoe S, Atsuta M, Yoneyama T, Matsumura H. Adhesive bonding of titanium-aluminum-niobium alloy with nine surface preparations and three selfcuring resins. Eur J Oral Sci 2003;111:170-174.

14. Petridis H, Garefis P, Hirayama H, Kafantaris NM, Koidis PT. Bonding indirect resin composites to metal: part 2. Effect of alloy surface treatment on elemental composition of alloy and bond strength. Int J Prosthodont 2004;17:77-82.

15. Barzilay I, Myers ML, Cooper LB, Graser GN. Mechanical and chemical retention of laboratory cured composite to metal surfaces. J Prosthet Dent 1988;59:131-137.

16. Seimenis I, Sarafianou A, Papadopoulos T. Shear bond strength of three veneering resins to a $\mathrm{Ni}-\mathrm{Cr}$ alloy using two bonding procedures. J Oral Rehabil 2006;33:600-608.

17. Matsumura H, Tanoue N, Yanagida H, Atsuta M, Koike M, Yoneyama T. Adhesive bonding of super-elastic titaniumnickel alloy castings with a phosphate metal conditioner and an acrylic adhesive. J Oral Rehabil 2003;30:653-658.

18. Petridis $H$, Garefis $\mathrm{P}$, Hirayama H, Kafantaris NM, Koidis PT. Bonding indirect resin composites to metal: part 1 . Comparison of shear bond strengths between different metalresin bonding systems and a metal-ceramic system. Int $\mathbf{J}$ Prosthodont 2003;16:635-639.

19. Matinlinna JP, Ozcan M, Lassila LV, Vallittu PK. The effect of a 3-methacryloxypropyltrimethoxysilane and vinyltriisopropoxysilane blend and tris(3trimethoxysilylpropyl) isocyanurate on the shear bond strength of composite resin to titanium metal. Dent Mater 2004;20:804-813. 